\title{
THE EVALUATION OF FINANCIAL STANDING OF MEDICAL INSTITUTIONS IN POLAND
}

\section{EDYTA MIODUCHOWSKA-JAROSZEWICZ}

\begin{abstract}
A B S T R A C T
The aim of the article is to identify the criteria and methods for the evaluation of medical institutions. The article uses economic analysis, comparative analysis, and methods of descriptive statistics. The analysis of existing regulations, source materials, and the specific business character of health care entities indicates the need to evaluate these units with particular regard to the criteria such as costs, quality of assets (level of consumption, i.e., wear and tear and modernness), employment, financial liquidity or the level of debt. The results of the study are the basis for the evaluation of the healthcare sector. The value of the article is in showing the direction taken by the evaluation of the financial standing of entities. The ability to use specific criteria and methods of evaluation for health care entities in business practice.
\end{abstract}

KEY WORDS

financial standing, medical institution, healthcare sector, evaluation

DOI: 10.1515/emj-2017-0013
Corresponding author:

Edyta Mioduchowska-Jaroszewicz

Department of Business Analysis and Strategy, Institute of Economics, University of Szczecin, Poland e-mail: edyta.mioduchowskajaroszewicz@usz.edu.pl

\section{INTRODUCTION}

The subject literature and business practice share two approaches to financial management of health care entities ${ }^{1}$. One approach indicates that medical institutions should be treated as business enterprises,

1 For stylistic correctness, the article uses the term 'medical institution' and its synonyms, such as health care entity, health care providers, etc. from which it is required to operate according to the fundamental principles of the market economy, not considering the specific nature of health services market (Wiercińska, 2014, p. 5). The second approach suggests that medical institutions are characterised by specific features distinguishing them from other sectors; however, they need to meet the same managerial requirements and the same level of professional 
management as organisations in any other field of activity (Rój \& Sobiecha, 2006, p. 73). Yet, the recent changes in regulations on medical institutions, the Act on Health Services and certain other acts which entered force on 15 July 2016 (Ustawa..., 2011) mapped out a clear course of action for the financial management of these entities.

The aim of this article is to identify the criteria and methods for evaluation of medical institutions, especially those that operate in the form of SPZOZs - Independent Public Health Care Entities - the traditional status of public health care facilities when not corporatized (Improving the financial sustainability of the hospital sector: towards a systemic approach. Policy Note, 2014, p. 35).

The article discusses the following:

- changes in legal regulations on medical institutions,

- sources of information used in the assessment of the financial condition of health care entities,

- criteria and methods for financial evaluation of medical institutions,

- the financial standing of healthcare sector entities in the years 2002-2014,

- conclusions.

For the purpose of this article, the Author formulates the thesis that financial ratios used to evaluate enterprises can also be applied in the evaluation of medical institutions.

\section{LITERATURE REVIEW}

It is important to underline the Act amending the Act on Health Services and certain other pieces of legislation that entered force on 15 July 2016 (Ustawa..., 2011). One of the amendments prohibits disposal of majority shares in companies managing medical entities, i.e., decommercialization of hospitals. The Act introduces several other regulations, among others, abolishes compulsory insurance against medical events and replaces the term 'enterprise' with the term 'medical institution' as the term clearly referring to medical activity. Moreover, the Act replaces the term 'negative financial result' with the term 'net loss' as a term used in the Accounting Act (Zdrowie ABC). According to the Act, an SPZOZ (Independent Public Health Care Entity) covers the net loss by reducing equity capital. In the case where the equity capital is not sufficient to cover the net loss, the entity is obliged to pay the remainder but not more than the amount resulting from the sum of the net loss and depreciation costs. While in the case where it is impossible to cover the net loss, an SPZOZ undergoes a commercialization or liquidation process (Gazeta Lekarska).

The current Act on Health Services defines economic categories allowing to evaluate independent public health care entities (SPZOZ) but only during their transformation into capital (commercialized) companies. Forming of an SPZOZ on the basis of incomes taken from the financial statement for the last fiscal year and the data on liabilities and shortterm investments as of the day preceding the day of submitting an application for registering a capital company in the business register, determines the debt ratio of the SPZOZ (Ustawa..., 2011, pp. 78-80).

The Act defines the debt ratio as the sum of short-term and long-term liabilities, less short-term investments of an SPZOZ to total income (Ustawa..., 2011, p. 71). This ratio is calculated as follows:

$$
\frac{L-C}{I}
$$

where:

$\mathrm{L}$ - long and short-term liabilities,

C - short-term investments (cash and short-term bonds),

I - total income.

The interpretation of the debt ratio in accordance with the position 70 and 71 of the Act on Health Services of 15 July 2016 is as follows (Ustawa..., 2011, p. 72):

- the ratio $>0.5$ denotes that the forming entity prior to the day of transformation/commercialization assumes the liabilities of an SPZOZ of the value not greater than 0.5 ;

- the ratio $\leq 0.5$ denotes that the forming entity prior to the day of transformation/commercialization can assume the liabilities of an independent public health care entity (SPZOZ). Liabilities due the longest time covering the total amount together with interests are assumed in the first instance.

The Act on Health Services does not specify more economic categories linked to the financial evaluation of such entities. This means that managers of health care entities face serious problems in defining criteria to determine the scope, standards and methods for the evaluation, regardless of the legal form, e.g., independent public health care entity, budget entity, foundations, associations or research units. Diverse legal forms of medical institutions regulated 
by the Act on Health Services significantly impedes on the evaluation process.

Sources of information used in the evaluation of the financial condition determine the possibility of their assessment. A medical institution, such as an independent public health care entity (SPZOZ), prepares financial statements, such as the balance sheet or the profit-and-loss account, and provides additional information. Health care entities that function in the form of budget entities and are governed by the local government unit are included in the statement of the local government unit.

Independent public health care entities (SPZOZs) wrestle with the duality of the law. In terms of the accounting, they should apply the Accounting Act. On the other hand, the accounting is regulated by the provisions of the Act on Health Services and the financial reporting of public finance sector units. Users of the information coming from the accounting, on the one hand, are private equity companies, and on the other hand, however, public entities, such as the National Health Fund (Narodowy Fundusz Zdrowia) or forming entities. From the point of view of independent public health care entities, it is important to underline the fact that the data coming from the accounting may be the basis for taking actions related to their existence, i.e. transformation or liquidation. The Act on Health Services imposes on forming entities obligatory actions that must be taken in the event of a negative financial result of SPZOZs and, consequently, the assumption of liabilities of such entities. Therefore, the accounting of an SPZOZ should be carried out in a way allowing to avoid any disturbances in the evaluation of the financial position and the financial result of such entities (Wawrowski, 2014).

A comprehensive evaluation of the economic and financial situation of health care entities, in addition to basic financial statements, i.e., depending on the legal form, should be made using all internal and external data that are generated for informational purposes or for improving management, etc. (Mioduchowska-Jaroszewicz, 2010, p. 22).

\section{RESEARCH METHODS}

Financial analysis is one of the instruments used by corporate management. It deals with assessing the financial and economic situation using specific procedures and methods (Pur, Jacova \& Horak, 2015, p. 5). Knápkova (2013) stated that financial analysis serves for making a complex assessment of the financial situation in a particular company. Already in 1979, Baruch and Shyam, 'claimed the extensive use of financial ratios by both practitioners and researchers is often motivated by tradition and convenience rather than resulting from theoretical considerations or from a careful statistical analysis. Basic questions, such as: Is the control for firm size, a major objective of the ratio form, called for by the theory examined; what is the structural relationship between the examined variables and size; and what is the optimal way to control for industry-wide factors, are rarely addressed by users of financial ratios'.

The use of analysis ratios is still very popular and has always been an important source of information about the financial health of entities. Determining the performance of a firm with the help of a set of financial measures/ratios has been an interesting and challenging problem for many researchers and practitioners. Identification of factors (i.e., financial measures/ratios) that can accurately predict the performance of a firm is of great interest to any decision maker (Dursun, Kuzey \& Uyar, 2013).

The analysis of the financial and economic situation of any entity is essential for its functioning. Due to the specific nature of medical institutions, it is essential to evaluate the economic and financial standing, taking into account the following elements:

- costs,

- the quality of assets (the level of consumption, i.e., wear and tear and modernness),

- employment,

- financial liquidity,

- the level of debt.

The evaluation of costs is an important part of the economic and financial analysis of health care entities. The cost analysis aims to provide detailed information on the costs in various sections, which is necessary for the causal assessment of the present level of costs, for disclosure of reserves, thus setting out the course of action and finding practical measures to increase the effectiveness of management by rational use of disclosed reserves (Waśniewski, 1981, p. 146). Costs in each business activity play an important role since they are the carriers of various economic information necessary for decision making in managing a business entity. They are important measures of performance of a given business activity as they reflect the entire business of the company, i.e., the effects of work on all the stages of creating the value for all stakeholders (Waśniewski \& Skoczylas, 
2003, p. 209), and in the case of health care institutions, the value for customers or patients.

A preliminary analysis of costs by function and type, performed along with the assessment of the changes in the structure of these costs, only allows determining the items of costs where deviations appeared in relation to the base, not explaining the reasons. This stage of the analysis allows to determine the nature and weight of the revealed deviations (cost reduction or overrun) and paves the way for further causal research (Waśniewski \& Skoczylas, 2003, pp. 218-219).

Fixed assets are mainly the subject of the asset quality analysis of health care entities. The assessment of asset quality of health care entities should include:

- the analysis of the size and the structure of fixed assets,

- the evaluation of consumption (wear and tear) and replacement or renewal of fixed assets,

- the study of the efficiency of fixed asset utilisation.

In making strategic decisions on the functioning of the studied entity, it is important to determine the level of and changes in the structure as well as the condition and the size of fixed assets. In the analysis of the size and structure of assets of the health care entity, the following issues should be considered:

- the size of fixed assets (absolute or relative difference ratios, indicators of growth),

- the structure of fixed assets (the ratio of fixed assets to the total value of fixed assets, the ratio of investment to the total value of fixed assets).

The analysis of the size of assets is to indicate how the total value of the assets behaves, whether it increases or decreases. The increase in the value is a positive sign as it means that obsolete fixed assets are properly renewed or replaced. The analysis of the structure of fixed assets should characterise the share of individual groups of fixed assets in the overall size of fixed assets (Jerzemowska, 2006, p. 198). Another crucial element in the evaluation of the quality of assets is the consumption and replacement of assets. Consumption of fixed assets reflects the decrease in their use and the replacement value. The use value decreases gradually over the useful life of assets, while the wear and tear increases. The causes of wear and tear of fixed assets, among others, are the heat or mechanical or chemical actions bringing about internal or external changes, thus inevitably leading to physical deterioration. Usually, these changes occur slowly over time, but may well occur suddenly as a result of excessive dynamic loads. Because of physi- cal wear and tear, technical parameters of fixed assets gradually worsen, which is reflected in frequent breakdowns, higher energy consumption or defects in produced goods. The process also lowers the value of fixed assets (Jerzemowska, 2006, p. 198).

The next step in assessing the quality of assets of health care entities is their efficient utilisation, which should enable (Borowiecki, 1993, p. 99):

- a comprehensive assessment of fixed assets,

- defining the impact of fixed asset utilisation on production and financial results,

- disclosing the existing reserves in fixed assets and indicating the possibilities of their effective use,

- determining the relationship and the optimal ratio between labour inputs,

- predicting the value of production, depending on the decisions relating to technical, economic and organisational objectives within the company.

The analysis of employment in the enterprise is conducted depending on the decision-making needs. Traditionally, it is based on the analysis of employment by a business category of the company and the kind of activities performed by employees. In practice, the evaluation of employment generally includes the assessment of the human capital in terms of changes in the presented classification categories. The analysis of the size and the structure of employment should cover employment flows, remuneration and the factors influencing them as well as productivity and profitability (Jerzemowska, 2006, p. 308).

The analysis of professional qualifications is the most important part of the employment analysis of health care entities. Professional qualifications are determined by such factors as theoretical knowledge, experience connected with vocational education, practical skills and work experience. Many of the qualifications are determined by qualitative factors, but their measurement is difficult or can be evaluated by descriptive methods only. Therefore, the assessment of personnel qualifications is usually limited to the study of the level of education and work experience.

For the analysis of the human capital, it is important to assess the employment flow rate. In assessing this factor, special attention is paid to redundancies and hiring new staff. In medical institutions, special attention is paid to the flow of workers mainly due to two factors. These are, firstly, justified redundancies, i.e., collective redundancies causing cost increase due to redundancy pay, reducing the number of employees due to technical and organisational changes or redundancies due to objective reasons. Secondly, 
from the perspective of employers, undesirable or unjustified redundancies, among others, due to resignations at an employee request, dismissal of employees on disciplinary grounds or job abandonment. Unjustified redundancies result in a significant increase in costs connected with hiring and training of new employees. Moreover, they adversely affect the morale and work discipline, job performance, and production. The main determinant of undesired redundancies is poor management of human capital resulting from abnormal remuneration policy, limited opportunities for promotion and raising qualifications, unsatisfactory social and living conditions, low job security and a stressful work atmosphere. Undesired redundancies are also the effects of labour discipline violations.

The assessment of the employment flow should be carried out based on the comparative analysis in time, and it should have a downward trend. The employment flow rate at the level of $15 \%$ is an indication that in the studied company the management of human resources is incorrect and that the value of this indicator should be decreased (Jerzemowska, 2006, pp. 309-310).

Another crucial issue considered in the analysis of employment is the assessment of remuneration due to importance in motivating employees to achieve aims of the company. It is also a powerful communication tool because the paid amount informs employees of how the company evaluates their contribution in generating the company's value, how much it is willing to pay for it, and what requirements must additionally be met by workers to receive a higher pay.

The assessment of labour efficiency in a health care entity is a reflection of human capital effectiveness. The concept of the effectiveness of human capital refers to the means of measuring and expressing the results of human labour. In general terms, labour efficiency is a measure of production, expressed in the natural or contractual unit or in terms of value achieved over a time unit. In practice, labour efficiency is measured by referring the amount of revenues to an average employment.

The assessment of labour efficiency should be complemented with the analysis of labour costs, which should include: the study of the labour costs and their changes over time as well as the structure and dynamics of the components and links between the labour costs and job performance (Jerzemowska, 2006, pp. 312-314). The evaluation of employment, taking into account the abovementioned aspects, allows to perform a multidirectional analysis of human resources and contributes to raising the efficiency of health care entities.

The most important current problem of any type of business, as well as healthcare institution operating in a market economy, is to maintain liquidity, i.e., the capacity for timely payment of liabilities. The aim of liquidity management is to enable the achievement of objectives such as (Wędzki, 2000, p. 110):

- maximising profits or minimising costs,

- maintaining a minimum level of cash,

- maintaining a minimum level of inventory,

- reaching a target value of the current ratio,

- reaching a target value of the quick ratio, the share of current liabilities in assets and debt service coverage ratio.

The analysis of liquidity should be performed in two stages, i.e., firstly, static analysis based on the study of liquidity derived from the balance sheet, and secondly, dynamic analysis based on the assessment of the cash flow statements (if published by the entity). Liquidity ratios, comparing the company's most liquid assets to the potential chargeability potential, offer a quick way to assess the degree to which the economic entity meets short-term obligations (Vasiu, Baltes \& Gheorghe, 2015, p. 188).

The static analysis of financial liquidity was to determine the degree of relationships between individual components of assets and liabilities and to organise them according to the degree of timeliness (Waśniewski \& Skoczylas, 2003, p. 429). The items taken under consideration in the dynamic analysis of financial liquidity are, for instance, the preliminary assessment of a financial situation, ratio analysis of the cash flow structure, cash sufficiency and cash performance (Sierpińska \& Wędzki, 2001, p. 52).

The level of debt is an important factor for managers, as it informs them of the possibility of being granted another loan by creditors and for investors who want to know whether the company is not too heavily indebted. It is one of the basic criteria for evaluating the financial situation of the company as well as a factor affecting its solvency. (MioduchowskaJaroszewicz, 2007, p. 352). In the case of financial ratios, the debt ratio (1), as enshrined in the Act on Health Services (Ustawa..., 2011), should always be considered. 
Tab. 1. Formulas of the ratios used in the analysis of the healthcare sector

\begin{tabular}{|l|c|l|}
\hline \multicolumn{1}{|c|}{ NAME } & ABBR. & \multicolumn{1}{c|}{ FoRMULA } \\
\hline Return on Operating Assets & RoOA & Operating Income / Average Operating Assets \\
\hline Return on Equity & ROE & Net profit / Average Equity \\
\hline Net Profit Margin & NPM & Net Income / Net Sales (revenue) \\
\hline Economic Return on Sales & EROS & (Operating Income + Depreciation) / (Sales Income + other Operating Incomes) \\
\hline Current Ratio & CR & (Current Assets-Long Term Receivables)/Current Liabilities \\
\hline Quick Ratio & QR & $\begin{array}{l}\text { (Short term Investments + Short-term Receivables - Long term Receivables) / } \\
\text { Current Liabilities }\end{array}$ \\
\hline Cash Ratio & CHR & Short term Investment / Short-term Liabilities \\
\hline Receivables Collection Period & RCP & (Average short term Receivables*365) / Sales Income \\
\hline Liabilities Payment Period & LPP & (Average short term Liabilities*365) / Sales Income \\
\hline Inventory Turnover & IT & (Average Inventory*365) / Sales Income \\
\hline Equity to fixed assets ratio & EFA & (Equity + Long term Reserves) / (Fixed Assets + Long term Receivables) \\
\hline Sustainability of Financing & SoF & $\begin{array}{l}\text { (Equity + Long term Liabilities + Long term Reserves) / (Fixed Assets + Long term } \\
\text { Receivables) }\end{array}$ \\
\hline Total Debt & TD & Liabilities and Reserves for Liabilities / Total Assets \\
\hline
\end{tabular}

Source: own elaboration based on (Zaleska, 2005, pp. 78-81; Waśniewski \& Skoczylas, 2004, pp. 310-318; Mioduchowska-Jaroszewicz, 2005, pp. 73-76).

\section{RESEARCH RESULTS}

The analysis of the financial standing of any entity should be based on comparisons. The simplest kind of comparisons are, of course, comparisons over time and according to a plan (i.e., when medical entities draw up plans and forecasts). Comparisons in space are often a problem not only for the assessment of the financial position of healthcare institutions but also of other types of businesses. Since 2005 Rachunkowość (Accounting Magazine) has published indicators, covering the data from the year 2002; thus, filling the information gap and allowing to make comparisons in space. Sector indicators published in Rachunkowość include 96 PKD sections (Polish Classification of Activities); thus, it also includes PKD section number 86 since the year 2009 called Human Health Services. The number of study subjects varied from a year to a year and the availability of data. The research used in the article, on which the author bases their research, is based on the number of companies surveyed since 2008. The average number of entities, which differed depending on the survey type, was 532 in 2008, 756 in 2009, 699 in 2010, 1019 in 2011, 592 in 2012, 773 in 2013 and 1244 in 2014.
On this basis, it was possible to conduct the analysis of the financial standing of the healthcare sector based on the assessment of criteria, such as: profitability (operating profitability of assets, equity, net sales and economic sales), liquidity (current, quick, cash, collection period, repayment period and inventory turnover), debt (equity to fixed assets ratio, sustainability of financing, total debt). The financial condition of the healthcare sector in the years 20022014 was analysed with the use of standard indicators whose formulas are listed in Tab. 1.

The profitability analysis of the healthcare sector was based on the arithmetic means of the ratios of operating profitability of assets, equity, net sales, and economic sales. The trend of the profitability ratios of using capital and consumption of production factors was significantly volatile in the years 2002-2014. Medical entities were characterised by the highest efficiency of capital and sales in the years 2006-2008. In 2008 , the average return on equity was the highest, and it amounted to $29.4 \%$. The weakest return on equity was recorded in the years 2002 and 2003 as it decreased to $-0.89 \%$ and $-0.74 \%$, respectively. From 2010 to 2014 , the profitability ratios were characterised by a consistent trend. Such a trend paves the way for the efficient management of these entities. 


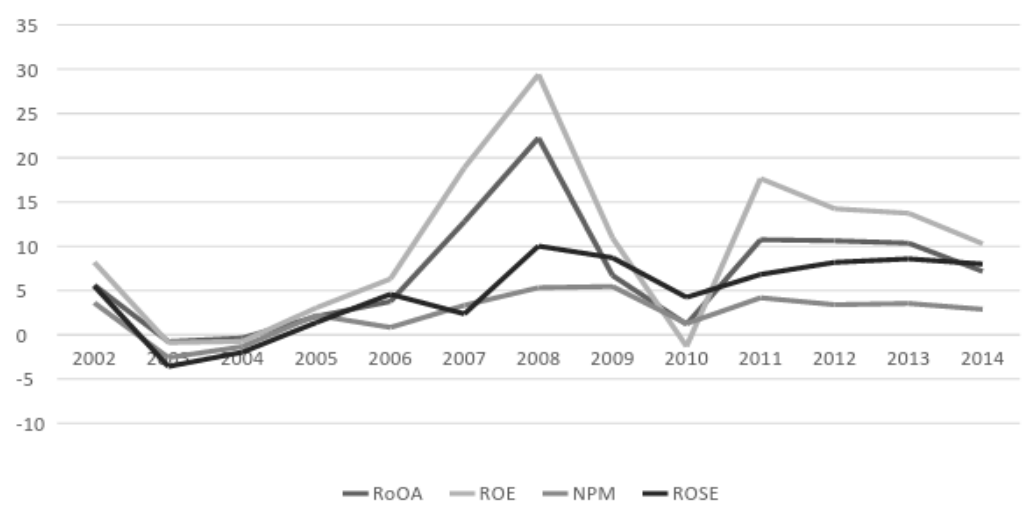

Fig. 1. Profitability of the healthcare sector

Source: own study based on Appendix - Tab. 1.

The analysis of liquidity was carried out based on the values of the current, quick and cash ratios in the years 2002-2014 (Fig. 2). The assessment of these ratios indicates an upward trend of these values; even though the values of all the ratios began to fall in 2014. Analysing the values of liquidity ratios, it should be noted that the healthcare sector is characterised by high values compared to the values of the same ratios in the manufacturing sector. First, the average values of cash liquidity exceed the standards calculated for manufacturing companies. This means that the healthcare sector is characterised by high levels of cash; whilst a small difference between the values of the current and the quick ratios (graph lines of $\mathrm{QR}$ and $\mathrm{CR}$ nearly overlap) informs that despite the specific nature of this sector, in which it would seem that a high level of inventory is necessary for the proper functioning of health care entities, these entities maintain low inventory levels. The high value of liquidity ratios is certainly safer for these entities, which is extremely important from the point of view of clients-patients.

The analysis of the ratios of short-term liabilities, short-term receivables, and inventory turnover in the years 2002-2014 shows that their values varied considerably. The analysis of the liability ratios revealed that the turnover of receivables in the healthcare sector amounts to no more than 30 days, which means that the collection period for deferred payments is very good. The period for the payment of liabilities is shorter than the collection period, which reflects very good liquidity of the healthcare sector as it can pay its liabilities quicker than it gets receivables. The average period of liabilities payment is up to 30 days. The healthcare sector is also characterised by a low level of inventory holding because, in the period under analysis, it is less than 10 days and only in 2002 it amounts to 16 days. The low ratios of short-term receivables, liabilities, and inventory turnover indicate the high efficiency of current assets and a positive cash flow.

The debt analysis shown in Fig. 3, based on the debt ratio (liabilities to total assets), indicates an upward trend of the analysed value. This means that in the studied healthcare sector, the debt level in the years 20082014 increased and on average amounted to $40 \%$. Given the average value of the debt ratio, it can be stated that its value is not high, and, thus, it is not dangerous for this sector. The value of the ratio $>50 \%$ indicates a high level of debt and an increased financial risk for the healthcare sector. However, within the sector, there are entities whose debt level amounts to almost 100\%, which is indicated by the maximum value of the ratio close to $99 \%$. There are also medical institutions whose debt level is zero. Nevertheless, considering the average values of profitability and liquidity ratios, the analysed debt level provides a financially stable and efficient functioning of the healthcare sector.

\section{CONCLUSIONS}

The thesis formulated in the article stated that financial ratios used to evaluate enterprises could also be applied to the evaluation of medical institutions. The standards adopted for financial indicators in the manufacturing sector do not apply to the interpretation of financial ratios calculated for the medical entities. This has been confirmed by the analysis of the data derived from the standard financial ratios.

The analysis of the financial ratios calculated for the collected data of the healthcare sector has shown that:

- the ratios take correct values that can be interpreted,

- the ratios allow determining mean values acceptable as standard values,

- measuring and assessing the data from the healthcare sector offers an opportunity for correct management of such entities.

Jacobs, Smith and Street (2013) also indicate that healthcare markets are not fully competitive; there- 


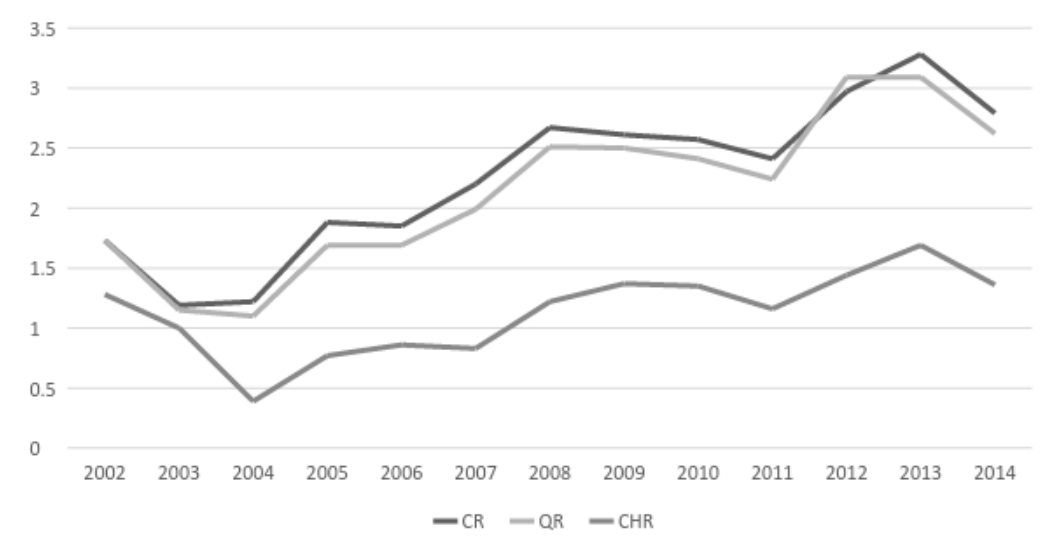

Fig. 2. Ratios of short-term receivables, short-term liabilities, and inventory turnover of the healthcare sector

Source: own study based on Appendix - Tab. 2 .

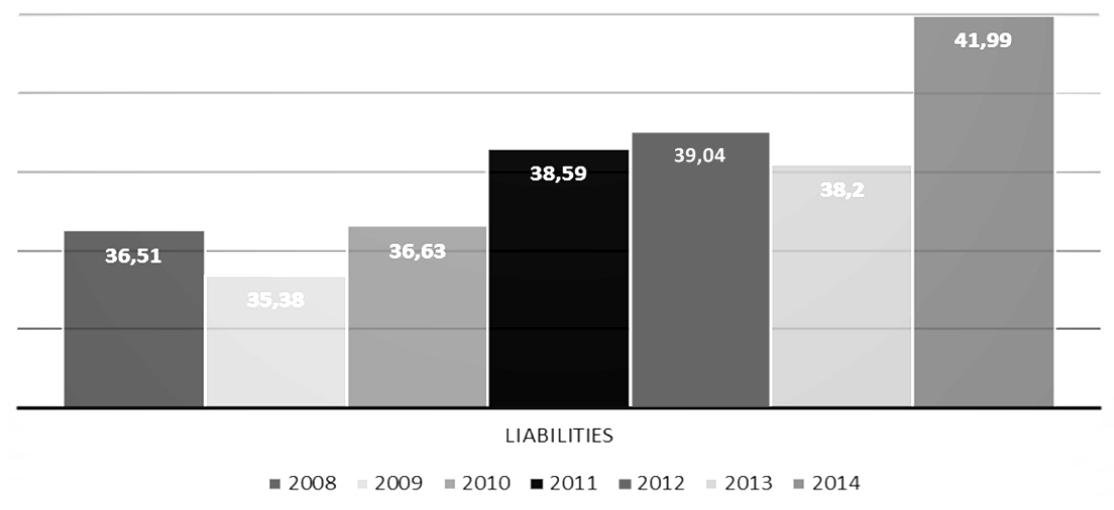

Fig. 3. Liabilities of the healthcare sector

Source: own study based on Appendix - Tab. 3.

fore, all the systems need some regulators. The most obvious need to introduce a regulator occurs when a large share of medical services is provided by the sector working for profit. In a situation where the system is dominated by public providers, the regulatory function may be performed by the government to exercise the supervision over the healthcare sector. Effective regulation plays an important role in promoting public safety. In addition, it requires measures allowing to evaluate the level of functioning of providers and to make comparisons.

According to Chluska (2014), the analysis of financial statements of health care entities poses significant problems both due to its procedures and determining and interpreting opinions based on this analysis. The specificity of the research environment of medical entities is influenced by factors such as:

- financial difficulties of health care entities resulting from limited resources of the sector that are a threat for ensuring the continuity of operations,

- using public funds to operate; hence, particular importance is attached to the rational financial management of medical entities and discipline of public finances,

- numerous restructuring processes,

- health benefits as an example of a specific product of an operating activity.

The changes in the Act on Health Services deprived health care entities of the non-profit status, where a negative financial result was not the reason for liquidation. Currently, medical institutions experiencing financial difficulties and incurring losses may be forced to transform or liquidate. Despite the independence in the management of health care entities, a forming entity's inability to cover losses and make a decision about the transformation or liquidation may result in a situation where liabilities of such an entity would burden the budget of the forming entity itself. Therefore, according to Wawrowski (2014b, p. 101), from the point of view of the supervisory function, it is important that owners of health care entities constantly monitor the financial standing and results of their units.

The article should be used as the reference base for analysing the financial configuration of medical entities because it contains a set of indicators and sources of information needed to make the right kind of analysis. An indicative analysis should be completed at each stage of the study for analysis of dynamics and structure. Most importantly, when evaluating the effectiveness of health care providers, it is important to assess changes in time and the structure of costs and revenues (MioduchowskaJaroszewicz \& Romanowska, 2016). The viability of 
the healthcare system depends on the financial soundness.

The capability of surviving in the market of the hospitals represent the basis of the system. Competent and robust financial management of hospitals is necessary. Financial ratios are crucial for the financial health of hospitals, relationships among the financial data of the economic units (including hospitals). Ratio analysis emphasises the need for achieving efficiency (internally) and effectiveness (externally) in operation dimensions which determine the competitive advantage that results in the return on equity above the average for the specific level of risk. The latter is affected by the capital structure and the liquidity conditions on the one hand (the financial point of view) and the investment in fixed assets (for the operational side of risk) on the other (Curtis \& Roupas, 2009, pp. 209-210).

\section{LITERATURE}

Baruch L., \& Shyam, S. (1979). Methodological issues in the use of financial ratios. Journal of Accounting and Economics, 1(3), 187-210.

Chu, D. K. W., Zollinger, T. W., Kelly, A. S., \& Saywell, R. M. (1991). An empirical analysis of cash flow, working capital, and the stability of financial ratio groups in the hospital industry. Journal of Accounting and Public Policy, 10(1), 39-58.

Chluska, J. (2014). Cel i zadania sprawozdań finansowych podmiotów leczniczych [The purpose and tasks of financial statements of healing subjects]. Studia Oeconomica Posnaniensa, 2(5), 7-18.

Curtis, P., \& Roupas, T. A. (2009). Health Care Finance, the Performance of Public Hospitals and Financial Statement Analysis. European Research Studies, 12(4), 199-212.

Dudycz, T., Hamrol, M., Skoczylas, W., \& Niemiec, A. (2005). Finansowe wskaźniki sektorowe - pomoc przy analizie finansowej i ocenie zdolności przedsiębiorstwa do kontynuacji działalności [Financial sector indicators - help with the financial analysis and the evaluation of the ability of the enterprise for the continuation of activity]. Rachunkowość, 3.

Dudycz, T., \& Skoczylas, W. (2006). Wskaźniki sektorowe za rok 2004 [Sector indicators for 2004]. Rachunkowość, 5.

Dudycz, T., \& Skoczylas, W. (2005). Wskaźniki sektorowe za lata 2002 i 2003 [Sector indicators for 2002 and 2003]. Rachunkowość, 3.

Dudycz, T., \& Skoczylas, W. (2007). Wykorzystanie wskaźników sektorowych do oceny przedsiębiorstwa [Using sector indicators for the evaluation of the enterprise]. Rachunkowość, 7.
Dudycz, T., \& Skoczylas, W. (2008). Wskaźniki sektorowe $\mathrm{za}$ rok 2006 [Sector indicators for 2006]. Rachunkowość, 5.

Dudycz, T., \& Skoczylas, W. (2009). Wskaźniki sektorowe $\mathrm{za}$ rok 2007 [Sector indicators for 2007]. Rachunkowość, 6.

Dudycz, T., Skoczylas, W. (2010). Ocena sytuacji finansowej sektorów w roku 2008 [Assessment of the financial situation of sectors in 2008]. Rachunkowość, 6.

Dudycz, T., \& Skoczylas, W. (2011). Sektorowe wskaźniki finansowe za rok $2009 \mathrm{i}$ ich porównywalności [Sector financial ratios for year 2009 and their comparabilities]. Rachunkowość, 4.

Dudycz, T., \& Skoczylas, W. (2012). Sytuacja finansowa przedsiębiorstw według sekcji i działów w roku 2010 [Financial standing of enterprises according to the section and departments of 2010]. Rachunkowość, 3.

Dudycz, T., \& Skoczylas, W. (2013). Wskaźniki finansowe przedsiębiorstw według działów (branż) za rok 2011 [Financial ratios of enterprises according to sections (of industries) for 2011]. Rachunkowość, 3.

Dudycz, T., \& Skoczylas, W. (2014). Sytuacja finansowa przedsiębiorstw według działów (branż) w 2012 roku [Financial standing of enterprises according to sections (of industries) in 2012]. Rachunkowość, 3.

Dudycz, T., \& Skoczylas, W. (2015). Sektorowe wskaźniki finansowe: wskaźniki finansowe przedsiębiorstw według działów (sektorów) za rok 2013 [Sector financial indicators: corporate financial indicators by sector (s) for 2013]. Rachunkowość, 3.

Dudycz, T., \& Skoczylas, W. (2016). Sektorowe wskaźniki finansowe: wskaźniki finansowe przedsiębiorstw według działów (sektorów) za rok 20142013 [Sector financial indicators: corporate financial indicators by sector (s) for 2014]. Rachunkowość, 3.

Dursun, D., Kuzey, C., \& Uyar, A. (2013). Measuring firm performance using financial ratios: A decision tree approach. Expert Systems with Applications, 40(10), 3970-3983.

Gołębiewski, G., \& Tłaczała, A. (2005). Analiza ekonomiczno-finansowa $w$ ujęciu praktycznym [Economic and financial analysis in the practical perspective]. Warszawa, Poland: Difin.

Groppelli, A. A., \& Nikbaht, E. (1999). Wstęp do finansów [Admission to funds]. Warszawa, Poland: WIG PRESS.

Helfert, E. A. (2004). Techniki analizy finansowej [Techniques of the financial analysis]. Warszawa, Poland: PWE. Retrieved from http://www.gazetalekarska. $\mathrm{pl} / \mathrm{p} \mathrm{p}=26046, \quad$ http://www.zdrowie.abc.com.pl/zmiany-w-prawie/15-lipca-2016-weszla-w-zycie-nowelizacja-ustawy-o-dzialalnosci-leczniczej,24287.html

Jerzemowska, M. (Ed.). (2006). Analiza ekonomiczna $w$ przedsiębiorstwie [Economic analysis in the enterprise]. Warszawa, Poland: PWE.

Jacobs, R., Smith, P. C., \& Street, A. (2013). Mierzenie efektywności $w$ ochronie zdrowia [Measuring the effectiveness in the health care]. Warszawa, Poland: Wolters Kluwer. 
Mioduchowska-Jaroszewicz, E. (2005). Metody i kierunki analizy wypłacalności przedsiębiorstw [Methods and directions of analysis of the solvency of enterprises]. Rozprawy i studia, Uniwersytet Szczecinski, 564, 73-76.

Mioduchowska-Jaroszewicz, E. (2007). Poziom zadłużenia w spółkach sektora budowlanego [Debt level in companies of the construction sector]. In D. Zarzecki (Ed.), Zarzadzanie finansami. Zarządzanie ryzykiem $i$ kreowanie wartości [Finance management. Risk management and creating value]. Szczecin, Poland: Wydawnictwo Naukowe Uniwersytetu Szczecińskiego.

Mioduchowska-Jaroszewicz, E., \& Romanowska, M. (2016). Profitability Evaluation of Hospital Departments Forming a Health Care Entity. Economics \& Sociology, 9(3), 224-234.

Pur, D., Jacova, H., \& Horak, J. (2015). An Evaluation of Selected Assets and Their Impact on the Declarative Characteristic of Ratio Indicators in Financial Analyses. Ekonomie A Management, 18(4), 132-149.

Rój, J., \& Sobiech, J. (2006). Zarządzanie finansami szpitala [Financial management of the hospital]. Warszawa, Poland: Wolters Kluwer.

Sierpińska, M., \& Wędzki, D. (2001). Zarządzanie płynności finansowa $w$ przedsiębiorstwie [Financial of liquidity mangement in the enterprise]. Warszawa, Poland: PWN.

Skalski, B. (2000). Badanie sprawozdania finansowego zakładu opieki zdrowotnej [The financial statements of the healthcare facility]. Rachunkowość-Audytor, 2(5).

Ustawa z dnia 15 kwietnia 2011 r. o działalności leczniczej [Act from 15 April 2011 about healing activity] (Dz.U. 2011 nr 112 poz. 654) 2011 (PL).

Waśniewski, T. (1981). Metody analizy finansowej $w$ przedsiębiorstwie [Methods of financial analysis in the enterprise]. Warszawa, Poland: PWE.

Waśniewski, T., \& Miklewicz, Z. (1994). Analiza finansowa $w$ gospodarce rynkowej [Financial analysis in a market economy]. Szczecin, Poland: Wydawnictwo Naukowe Uniwersytetu Szczecińskiego.

Waśniewski, T., \& Skoczylas, W. (2004). Teoria i praktyka analizy finansowej $w$ przedsiębiorstwie [Theory and practice of financial analysis in the enterprise], (pp. 310-318). Warszawa, Poland: Fundacja Rozwoju Rachunkowości w Polsce.

Waśniewski, T., \& Skoczylas, W. (1996). Kierunki analizy finansowej w przedsiębiorstwie [Directions of financial analysis in the enterprise]. Szczecin, Poland: Wyższa Szkoła Administracji Publicznej.

Waśniewski, T., \& Skoczylas, W. (1998). Syntetyczna ocena wyników oraz sytuacji finansowej przedsiębiorstwa [Synthetic evaluation of the results and the company's financial situation]. Rachunkowość, 4.

Wawrowski, R. (2014). Specyfika polityki rachunkowości samodzielnych publicznych zakładów opieki zdrowotnej [The specificity of the accounting policy of independent public health care]. Studia Ekonomiczne, 201, 393-403.
Wędzki, D. (2000). Strategie płynności przedsiębiorstwa [Strategies liquidity enterprises]. Warszawa, Poland: PWN.

Wiercińska, A. (2014). Specyfika zarządzania finansami szpitala [The specificity of hospital financial management]. Journal of Management and Finance, 12(2), 5-20.

Vasiu, D. E., Baltes, N., \& Gheorghe, I. N. (2015). Liquidity Ratios: A Structural and Dynamic Analysis, during 2006-2012, of the Companies Having the Business Line in Industry and Construction, Listed and Traded on the Bucharest Stock Exchange. Theoretical And Applied Economics, 3(604), 187-206.

Zaleska, M. (2005). Ocena ekonomiczno-finansowa przedsiębiorstwa przez analityka bankowego [Assessment of economic and financial business analyst banking]. Warszawa, Poland: Szkoła Główna Handlowa. 


\section{APPENDIX}

Tab. 1. Return on Operating Assets, Return on Equity, Net Profit Margin and Economic Return on Sales of the health care sector in Poland in the years 2002-2014

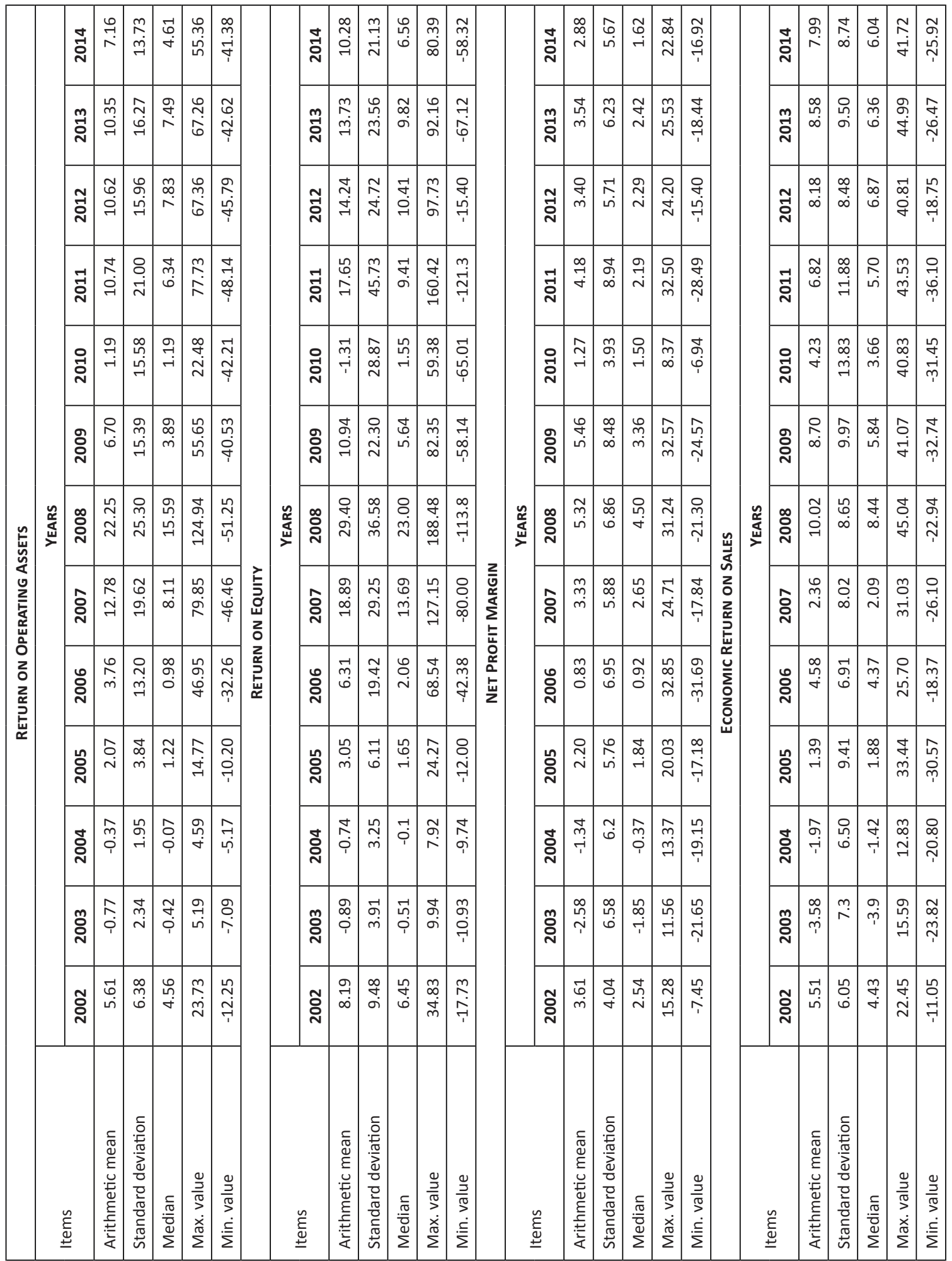


Tab. 2. Liquidity ratios of the health care sector in Poland in the years 2002-2014

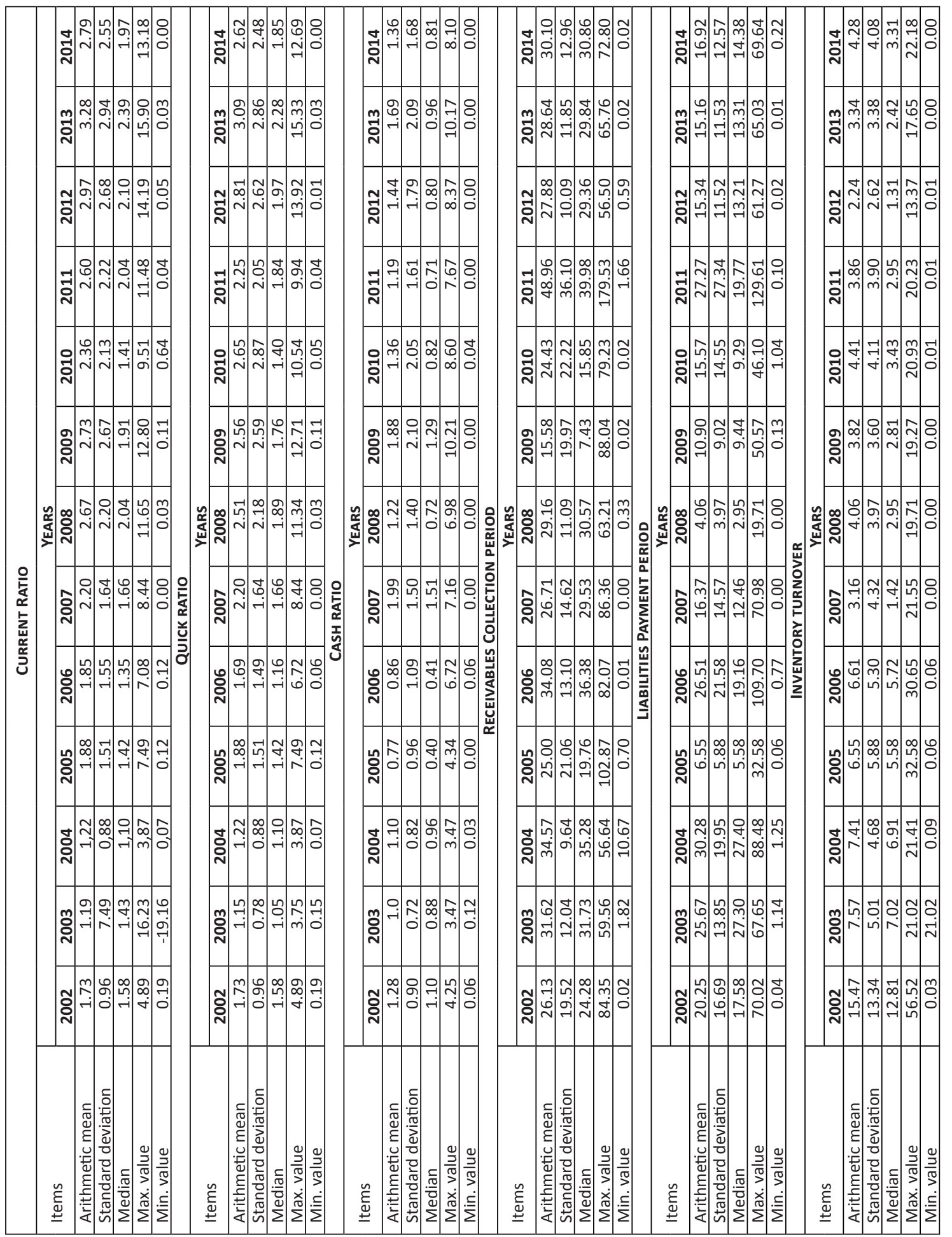

Source: own elaboration based on (Dudycz et al., 2005, 2006, 2007, 2008, 2009, 2010, 2011, 2012, 2013, 2014, 2015, 2016). 
Tab. 3. Debt ratios of the health care sector in Poland in the years 2002-2014

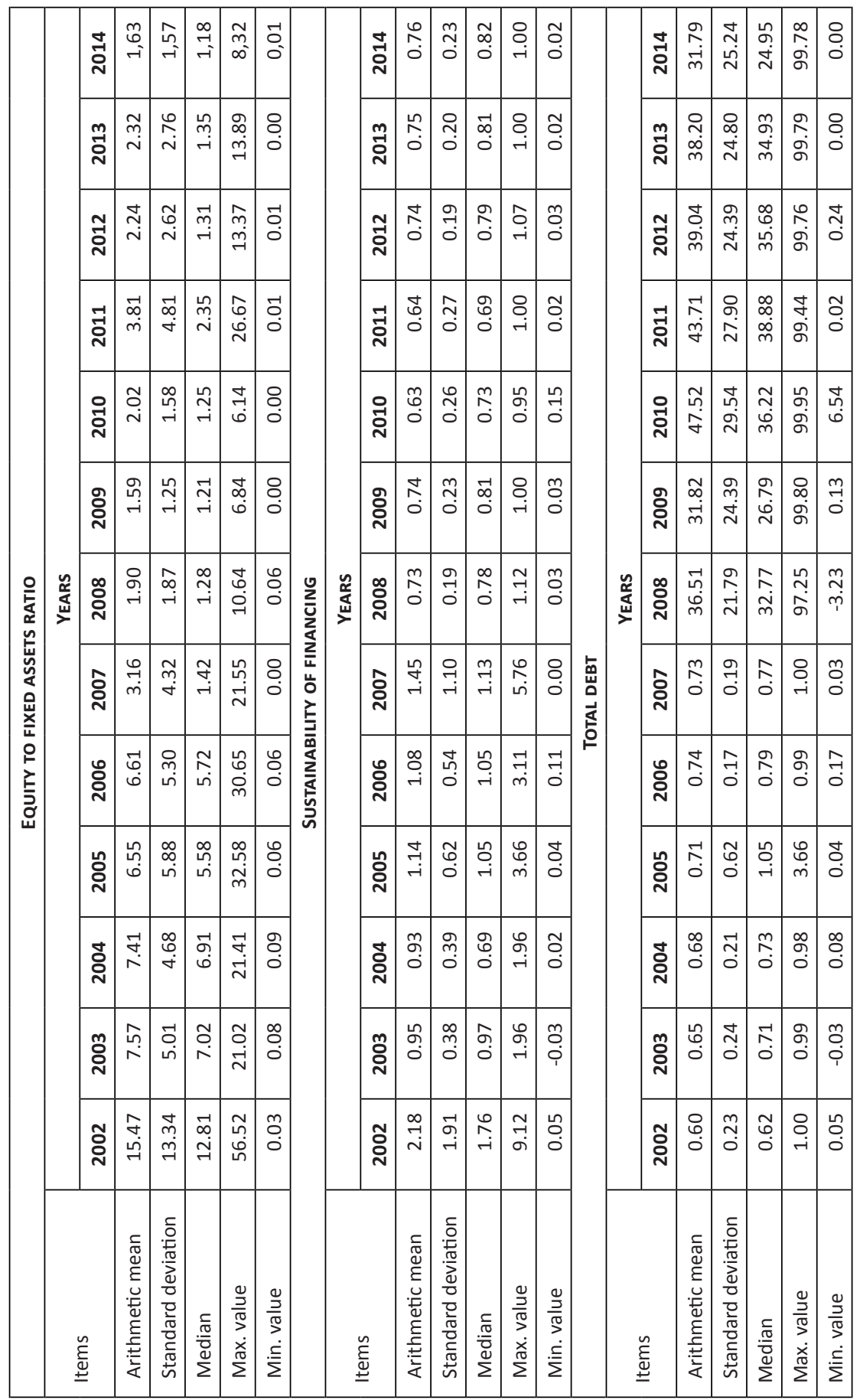

Source: own elaboration based on (Dudycz \& Skoczylas, 2005, 2006, 2007, 2008, 2009, 2010, 2011, 2012, 2013, 2014, 2015, 2016). 